\title{
Services Marketing and Medical Tourism: The Impact on Private Health Services in Bangkok
}

\author{
Prof Dr Paul James \\ Graduate School, Bangkok University \\ Klong-Toey, Rama 4 Road, Bangkok 10110 \\ Tel: 66-23-503-500 E-mail: paul.j@bu.ac.th
}

Received: Oct. 8, 2019 Accepted: Nov. 21, $2019 \quad$ Published: January 1, 2020

doi:10.5296/jmr.v12i1.15819 URL: https://doi.org/10.5296/jmr.v12i1.15819

\begin{abstract}
This is a research paper that is concentrated on assessing service marketing developments and medical tourism and its impacts on the of private hospital provision in Bangkok, in terms of rationale, application and engagement.

An interpretive methodology was utilised in order to help understand the senior marketing management perceptions underpinning hospital services marketing developments directed towards medical tourism. The scope for this research were private hospital on-site senior marketing teams. The population of interest was made up of 14 senior marketers located at multiple-site main health services offices.

The research outcomes consisted of three (3) Main Themes - Health Services Marketing Management, Health Services Unit Internal Management and Services Marketing Developments; ten (10) sub-themes; with 244 discussion targets.

The paper addresses a number of raised issues and establishes outcomes and implications for managing medical tourism within the private hospital sector in Bangkok.

Very little research has been conducted in this area in Bangkok and the paper addresses health service issues/reactions to Medical Tourism as being unclear, tentative and requiring more effective and robust services marketing developments.
\end{abstract}

Keywords: Service Marketing, Medical Tourism, Private Hospitals, Bangkok 


\section{Introduction}

The drive and level of international services marketing within private health services appears to be broadly supported in terms of value (Turner, 2007; Keckley \& Underwood, 2008); improved marketing communication (Karuppan, 2009); social media marketing mechanisms (James, 2015); product and service quality (Zeithaml, Berry \& Parasuraman, 1996; Clark \& Clark, 2007; Murti, Deshpande \& Srivastava, 2013); cost effectiveness (Rashdi, 2011; Hanefeld et al., 2013); reputation (Bhangale, 2011); and quality of facilities available (Li, Huang \& Yang, 2011). Further, in order to provide an appropriate level of trust from prospective patients living in another country, the service marketing elements of branding equity (Bello \& Holbrook, 1995); client satisfaction (Newsome \& Wright, 1999; Gill \& White, 2009); patient participation in decision-making (Fraenkel, 2013); and service development through the service chain, appears to be mandatory (James, 2005). Consequently, leaving one element unmanaged often results in failure for the whole service marketing chain (Voorhees, et al., 2017).

Private health services offer medical services appropriate to specific areas of expertise within a variety of disciplines - especially where this is associated with high-technology and consequent high cost. These service units have an operating business goal of making a profit (Raju \& Lonial, 2002) that provides the fiscal drive to function and operate (James, 2012) with added value (Hareide et al., 2016; Fraser, Encinosa \& Glied, 2008). Thus, private health services in Bangkok are now focusing on gaining additional revenue stream created through foreign patients. This is now moving more towards developing cross-border services that are likely to become more significant to the health services unit internal profit-generation ethos (Lin \& Lin, 2010) through additional marginal revenue and profits because of oversupply (Crane, et al., 2011) and inter-hospital competition (Mascia, Vincenzo \& Cicchetti, 2012). However, private health services tend to make a higher commitment to expending more on services marketing (Cutler \& Morton, 2013) than government counterparts and can afford to target more effectively through clearly defined patient service marketing channels (Young \& Erdem, 1996; James 2015).

In relation to profit requirements private health services appear to utilise additional elements of the marketing mix in order to establish and develop focused marketing related communications (James, 2015). This has led to changes in private health service provision, directed to additional management/marketing goals and internal processes in order to achieve this (Joynt, Orav \& Jha, 2014). Consequently, many health providers attempt to pursue a systematic service marketing strategy (Speziale, 2015) that offers medical facilities to well-off patients (James, 2012) especially those with medical insurance. However, this should be contrasted with the notion that most insurance companies do not cover cross-border medical interventions (TravelInsurance.com, 2017) and therefore the use of accident insurance as an indicator of medical tourism transactions is perhaps widely inaccurate and imperceptive. However, it is an anathema to consider those individuals using accident insurance for inclusion in cross-border medical treatment as the accident insurance is in case of an accident, not as part of a planned medical intervention. 


\section{Mll Macrothink}

Journal of Management Research

ISSN 1941-899X

2020, Vol. 12, No. 1

As hospitals are in a service sector, people, process and physical evidence are the additional factors associated with services through an extended marketing mix (Goi, 2009) by considering marketing practices (Thomas, 2005). Patients need to be informed and induced to engage through more focused hospital services marketing (Rivers \& Glover, 2008), as patients require very personalised medical solutions. Medical professionals cannot operationalise unless the whole team including nurses, administrators, professional technician's and those comprised within the supply chain work towards more effective medical services provision (Sinha, 2017; Gordon, Feldman \& Leonard, 2014). Inevitably, service marketing rests on all these incongruent individuals working together - and in the case of medical tourism - often at great distances. The engaged services marketing processes needed to work together so that the patient can safely, securely and comfortably move from home-hospital-home without risk or further injury and creates a need to consistently manage the service marketing strategy (Devers, Brewster \& Casalino, 2003). Matching process requirements with patient requirements appears to be a very difficult issue to attain through the marketing services chain (McFadden, Stock, \& Gowen, 2006). Further, services marketing developments in private health services tend to be motivated and constrained by government strategies and the regulators as a means to enhance service delivery (Al-Damen, 2017). This appears to be diametrically opposite the singular profit-oriented developments of private health provision (James, 2012).

Services marketing essentials that appear to be important in cross-border movement of patients (Horowitz \& Rosensweig, 2007) appears to be the perception of the standard of practicing medical quality (Lagiewsky \& Myers, 2008), responsiveness (Kanibir \& Nart, 2012; Sheaff, 2002), whilst being cost effective (Lynch \& Schalet, 1999; de Arellano, 2007). Changes in the service marketing prescription reflect different patient perceptions of heterogeneity (Grönroos, 1999), inseparability (Taner \& Antony, 2006) and perishability (James, 2005) and appear to adjust client satisfaction and perceptions of service quality (Zeithaml, Berry \& Parasuraman, 1996; Cronin, Brady \& Hult, 2000). Services marketing mechanisms including digital communications and appear to have profound effects today on medical services provision (James, 2015) as patients demand more personal approaches (Choi et al., 2004) and delivery of international level capability who can afford to make appropriate choices regarding their medical needs (Fischer, Pelka \& Riedl, 2015).

\subsection{Medical Tourism services marketing in Bangkok}

Medical tourism (including health tourism (Borman, 2004) and wellness tourism (Pyke et al., 2016) is not a new medical professional undertaking, which has been conducted in private hospitals in Bangkok on an ad-hoc basis (James, 2012). However, the term 'medical tourism' is still in flux (Kelley, 2013), undeveloped (Horowitz, Rosensweig \& Jones, 2007) and conditional (Carrera \& Bridges, 2006), which raises confusion regarding its interpretation and use (García-Altés, 2005; Kangas, 2010; Sobo, 2009). Further, it is fairly difficult to understand the true numbers involved in medical tourism (Connell, 2006) and in Thailand where conflicting published figures such as 920,000 hospital visits by expatriates (Bangkok Post, 2018) or another source estimated 320,000 (Bangkok Post, 2017) does little to help build appropriate meaning associated with medical tourism for Thailand's medical policy developers (Bochaton \& Lefebvre, 2008). 


\section{Ml Macrothink}

Journal of Management Research

ISSN 1941-899X

2020, Vol. 12, No. 1

Consequently, there is a need to be more precise with the terms used for patient's crossing-borders (Turner, 2010; Masoud et al., 2013). For the purposes of this research, medical tourism is the intentional, prearranged single purpose, non-emergency medical undertaking (Johnson, et al., 2010) and experience of medical procedures and interventions across borders (Footman, et al., 2014).

Having raised these issues (Arksey \& O'Malley, 2005), this creates the context for the research question, In what ways do strategic services marketing developments impact health service providers in relation to medical tourism in Bangkok?

\section{Methodology}

Assessing perceptions of services marketing developments relating to medical tourism creates a need to utilise a qualitative inquiry to help differentiate more effectively between the various issues within the research scope (Walsh, White \& Young, 2008). This research focuses on all senior-level marketing managers of private hospitals in Bangkok in terms of their opinions raised from their managerial experiences, as authoritive 'knowledge agents' (Benn et al., 2008; Sbaraini et al., 2011). This provides material observations (Sutton \& Austin, 2015) and adequately focused on the research concerns (Cassell \& Symon, 2004) regarding current services marketing practices in relation to medical tourism.

The research employed a semi-structured interview design process from a subjective knowledge perspective (Kvale, 1996) and reinforced by using an inductive/theory building approach (Glaser \& Strauss, 1967). This methodology was devised for constructing appropriate contextual data (Qu \& Dumay, 2011).

A closed population of fourteen (14), all contained within the research scope (Ritchie \& Lewis, 2003; Fink, 2000), were made up of all senior-level marketing managers who had on-going direct services marketing experiences. Respondents were chosen randomly through employing the approach of a population of interest (Carman, 1990) thus ensuring empirical adequacy (Spanos, 1990). A pilot study was carried out with three (3) randomly chosen respondents from the population and excluded from the main interview process (Maxwell, 2013) that endorsed changes to language and the logic of questions to respondents (Kim, 2011) and streamlined the question arrangements (James \& James, 2011). Eleven (11) respondents were interviewed, which were conducted in English and took approximately one hour each (Ward, et al., 2015; Sbaraini et al., 2011), audio-recorded with permission (Duranti, 2007) and interviewed using an identical set of prepared open questions (Gray \& Wilcox, 1995; James, 2014; Kvale, 1996). These questions were, supplemented using speculative probing questions (Balshem, 1991; Punch, 2014; Meurer, et al., 2007). Each interview was transcribed verbatim - applying the qualitative software package NVivo 11 (Bailey, 2008) was returned to each respondent for comment, correction, addition or deletion and return (Harris \& Brown, 2010; Irvine, Drew \& Sainsbury, 2012).

The complete raw interview data sets (Harwood \& Garry, 2003) was analysed and manually examined to create appropriate codes (Dey, 2005) and themes out of the thematic analysis (Glaser, 1992; Walsh, White \& Young, 2008; Charmaz, 2006) using NVivo 11. No portion of 


\section{Macrothink}

any expressed dialogue was left uncoded (Rubin \& Rubin, 2005; James \& James, 2011). Validity was increased using triangulation processes where appropriate (Onwuegbuzie \& Leech, 2007). Further, methodological coherence (Altheide \& Johnson, 1998) was preserved by relating the main research question to the data outcomes (Stenbacka, 2001). The expressed narrative that developed was based on substituting 'credibility' (Johnson, 1997) and ‘dependability' (Lincoln \& Guba, 1985) for 'reliability' (Strauss \& Corbin, 1990).

This research outcome uses authentic observations reflecting the narrative experience level of services marketing leaders underpinned by robust rigour (Seale \& Silverman, 1997) and the impact of their practices (Lambsdorff, 1998), designed to help build an analysis in the 'interests of the public good'.

\section{Results}

The research outcomes for this analysis is shown in Table 1 below and consists of three (3) main themes - Health Services Marketing Management, Health Services Unit Internal Management, and Services Marketing Developments; and ten (10) sub-themes with 244 discussion records. The respondent's voice is exposed through ad-verbatim conversations, where the reporting format is derived from Gonzalez (2008) and also Daniels, et al. (2007). 
Table 1. Outcomes - Research question, themes and discussion targets

\section{Research Question}

In what ways do medical tourism influence the strategic services marketing developments of private hospitals in Bangkok?

\begin{tabular}{|c|c|c|c|}
\hline Main-Themes & Sub-Themes & $\begin{array}{c}\text { Respondent } \\
\text { Citations }\end{array}$ & $\begin{array}{c}\text { Discussion } \\
\text { Targets }\end{array}$ \\
\hline \multirow[t]{2}{*}{$\begin{array}{l}\frac{\text { Health Services }}{\text { Marketing }} \\
\underline{\text { Management }}\end{array}$} & $\begin{array}{c}\text { Client Orientation } \\
\text { Marketing Materials } \\
\text { Communication } \\
\text { Developments } \\
\end{array}$ & $\begin{array}{l}5 \\
9 \\
1\end{array}$ & $\begin{array}{l}29 \\
25 \\
22\end{array}$ \\
\hline & & Total & 76 \\
\hline 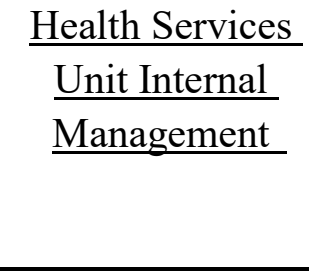 & $\begin{array}{c}\text { Language Provision } \\
\text { Doctor/Nurse Training } \\
\text { Medical Tourism Statistics } \\
\text { Privacy/Administrative } \\
\text { Arrangements } \\
\end{array}$ & $\begin{array}{c}7 \\
3 \\
11 \\
8\end{array}$ & $\begin{array}{l}19 \\
23 \\
26 \\
21\end{array}$ \\
\hline & & Total & 89 \\
\hline $\begin{array}{c}\frac{\text { Services }}{\text { Marketing }} \\
\underline{\text { Developments }}\end{array}$ & $\begin{array}{c}\text { Services Marketing } \\
\text { Orientation } \\
\text { Communications Channels } \\
\text { Technology Changes }\end{array}$ & $\begin{array}{c}2 \\
6 \\
6 \\
10\end{array}$ & $\begin{array}{l}32 \\
19 \\
28\end{array}$ \\
\hline & & Total & 79 \\
\hline
\end{tabular}

\subsection{Main Theme - Health Services Marketing Management}

In terms of Client Orientation this is typified by one respondent (5) who indicated that, ..W We don't connect directly to the foreign customer. We only see them when they arrive here. It takes time to understand their issues. Sometimes though customers contact our doctors. There has been a better communications when this happens...

In terms of Marketing Materials this is typified by one respondent (9) who indicated that, ... We are learning to use social media in their language that helps us when we are contacted by overseas customers, and they make the informed choice. Which is better for them, their physicians and $u s . .$.

In terms of Communication Developments this is typified by one respondent (1) who indicated that, ... Web pages are not new to us, but staff do not really look at it at all, as we follow instructions. I do not know what is being stated, as it changes too often as I am too busy to look at it... 


\subsection{Main Theme - Health Services Unit Internal Management}

In terms of Language Provision this is typified by one respondent (7) who indicated that, ... Patients can contact in a number of ways through our website. But contact is limited to e-mails and telephones. But our language capability is rather limited as little training is provided and it is too difficult...

In terms of Doctor/Nurse Training this is typified by one respondent (3) who indicated that, ...Some doctors have some English language. But many do not. It is still a problem. We try our best to have a translator available in all patient discussions. Sometimes that's not possible...

In terms of Medical Tourism Statistics this is typified by one respondent (11) who indicated that, ...It is difficult to know whether a foreign patient is living here or not. It's not our business. We only help with their medical needs, not where they come from. However, for foreigners we only take cash and this is a considerable problem...

In terms of Privacy/Administrative Arrangements this is typified by one respondent (8) who indicated that, ... Of course, our major responsibility is to protect medical data and keep it safe. However, one of the major issues is to verify such data, and that can be a problem especially for overseas customers...

\subsection{Main Theme - Services Marketing Developments}

In terms of Services Marketing Orientation this is typified by one respondent (6) who indicated that, ...I think the doctors and management need to get together to ensure we respond properly to changing international market conditions. We need them to direct us to economies that have many patients who will come here...

In terms of Communications Channels this is typified by one respondent (2) who indicated that, ... In so doing we can easily help them as they travel to us, because we can call on other professionals in the travel chain and make sure they are getting the best medical help prior to getting to us. It's not our responsibility though...

In terms of Technology Changes this is typified by one respondent (10) who indicated that, ...It is correct that we do not have really good understanding of marketing technologies or technologies to help with the patient. We have to get better and invest more...

\section{Discussion - Research Consideration and Implications}

The discussion focuses on the Main-theme elements where the explanations presented are considered "internally coherent" (Coombs, 2017), whilst maintaining respondent "confidentiality" (Kaiser, 2009). The outline discussion of the research implications for this study is shown in Table 1 above, configured as representing a robust induction from the data by using a persistent taxonomy approach (Westhues et al., 2008) and emerging from the narrative as below: discussion 


\subsection{Health Services Marketing Management}

In services marketing, client aspirations are very important. In this situation, underpinned by knowing the client through health records and personal discussions (Comandé, 2009). However, this is mostly done only when they arrive at the hospital, reflecting an underdeveloped services marketing chain. Social media developments may help bridge this service-chain component (James, 2015) enhancing the doctor-patient relationship through refined and targeted services (Cheek \& Chandra, 2002) and may provide further opportunities for supplementary revenue and profitability (Han \& Hyun, 2015; Jiang \& Rosenbloom, 2005). Additionally, through a more effective client orientation starting at the beginning of the process, doctors/patients will be able to assess the data corresponding to a patient's health condition, as this engagement will generate greater trust and reliance of the foreign doctor's capability and motivation (Yoon, Cho \& Suguaran, 2011).

It would appear from the data, that service support materials are often not in an appropriate language or packaged specifically for different overseas patients (Dooley, Jones \& Iverson, 2014). It is perhaps difficult to understand why this remains an issue. This may influence the level of overseas patient retention which is reportedly as low as 5\% (Han \& Hyun, 2015).

The data indicated that some private hospitals utilise face-to-face discussions, but these were reported as being rare. Thus, the development of mobile technologies and online technologies (Dimitrov, 2016) have introduced opportunities for change to the business operations of health marketing services environments (James, 2015). Further, most hospitals implement such new technologies only within their core medical diagnostic arena. The data indicated that the patient contact was mostly through a website or by telephone and that a lack of language skills has made the call difficult and led in some cases to the relationship being terminated - even before it starts. This is an example of a supply-side impediment (Bahadori, et al., 2017) that needs to be addressed.

\subsection{Health Services Unit Internal Management}

From the data, a major issue that was raised was the level of communication capability between the patient, doctor and other staff of the hospital, as patients do not appear to be able to easily discuss with staff such issues as present medical strategy, meals, administration and also insurance. This also applies to signatures for data access and also primary permissions forms especially as the only recognised legal language is Thai. Consequently, appropriate language provision is a difficult requirement to fulfil (Holmqvist, 2011), as there are latent costs and raised on-going legal problems associated with specialist communication and the loss of meaning within a service encounter through lack of suitable co-creation (Vargo \& Lusch, 2004). Limited language skills appear to interfere with normal hospital processes, thus reducing the value of the discussion and mutual understanding (Marcella \& Davies, 2004) leading to the possibility of creating unnecessary and significant health risks. Further, the doctor's understanding of what medical tourism patients require may be limited to the specialisation of their professional activity. However, the data suggests that dealing with different cultures poses a considerable challenge to ensure the adopted level and focus of services marketing, matches the patient's service needs and experiences (Holmqvist, 2011; 
Carman, 2000). In this respect, there appears to be a need to provide more language and culture courses for all health service personnel, as this is seen as very important to better understand foreign patients (Jacobs et al., 2004; Chauvot, 2011). The data further suggests that some specialist health centres also offer basic language in Arabic and even Korean - but these are not widespread.

Reliance on foreign clients - at 9\% in 2006, 14\% in 2010 and estimated at 22\% today (Noree, Hanefeld \& Smith, 2016) will affect the bottom-line. This expansion is seen as critical to the growth of health service development in Bangkok.

From the data, upon arrival at the hospital, all patients have to explain the reason for their visit to first-line administrators (non-medical staff) that is conducted in the "open" for anyone to listen to the conversation. Privacy is not a premium consideration. However, a simple administrative code or QR Code (Uzun \& Bilgin, 2016) and social media tracking systems should easily alert the first-line administrators of a medical tourism patient and then conduct the necessary administrative arrangements. Consequently, the data indicates that many patients were waiting for administrators to find out where the patient should go, which does not provide the necessary confidence that the efficacy of the arrangements for service quality provision were adequate (Owusu-Frimpong, Nwankwo \& Dason, 2010). However, this underpins the raised services marketing issues, as not one of the health service providers operate a certified services marketing system - for example within TEMOS (Ratner, 2012).

\subsection{Services Marketing Developments}

From the data, health services management appear reluctant to help patients move seamlessly from home-hospital-home and to provide medical supervision for patients whilst travelling. However, cross-border collaboration is likely to be hospital-to-hospital based (Glinos, 2011) rather than just through doctors only. This indicates building proper communications patterns and data management that will add pressures to on-going services marketing delivery.

Further, the evidence clearly indicates that in many instances, the cross-border destination doctor often has had no connection to the patient's home/origin doctor (Lunt, Hardey \& Mannion, 2010) which fails the "continuance" duty of care required by doctors - irrespective of borders. This does not therefore provide adequate "due diligence" regarding potential patient history. Therefore, this is a material failure of the communication-chain on behalf of the patient (Yoon, Cho \& Suguaran, 2011). The communication channel has therefore broken down and is a barrier to effective patient engagement (Rokni, Avci \& Park, 2017).

The data indicates clearly that no doctor used supported/structured transcriptions of medical discussions - as case summaries do not appear to have been translated very well or not at all resulting in medical clarification failure (Fry et al., 2017). The data presented indicates that doctor's lacked genuine ability to provide anything more than just short-hand field notes that were inadequate and potentially irresponsible (Phillippi \& Lauderdale, 2017; Ranney, et al., 2015).

The data indicated that in-house tracking of patients was conducted by some service providers through bar-codes entered into the service providers internal system. For example, the use of a 
QR Code tag system and a smartphone (including 2D information codes) (Uzun \& Bilgin, 2016). This helped develop a normalised internal patient tracking process from first-meet - and also ensure triangulation of ID sources to corroborate a patient's ID as well as medicine concerns, attempts at language conciliation and food requirements. However, such systems were not considered normalised.

\section{Conclusions}

The refocus of health services management towards overseas clients may add more supplemental value to the present medical services financial-stream. Confusion persists over whom is deemed a medical tourist, as private health services in Bangkok are not able to identify conclusively medical tourists except those in their own concentrated/limited supply chain. This misrepresents actual perceptions of medical provision/delivery to cross-border patients that are far below their presently stated numbers. Further, there does not appear to be an effective oversight of those entities engaged in medical tourism (Smith, Lunt \& Hanefeld, 2012) and this can create barriers to building trust and appropriate encouragement of service channels through ineffective financial arrangements (Nagarajan, 2004). Thus, the effectiveness of strategic service marketing orientation is brought into question and it also negatively affects the credibility of their present medical service engagement, their developed brand and makes the efficacy of their marketing strategy for "medical tourists" ineffective.

For "medical tourism" patients, underpinning effective services marketing provision, there is a need to reassess the official languages used, in order to ensure the majority of staff fulfil the language/cultural requirements. With continual training and the building of connections to hospitals overseas, creating more effective communications directly between actors in the service chain may help to quickly resolve medical issues raised through the medical tourism process. The ultimate goal would be to seamlessly provide appropriate cross-border medical services that offer patients value for money and a quicker means to resolve their medical problems.

Changes to the present services marketing provision - that have structural and managerial impacts - need to be carried out using a rigorous approach in order to ensure appropriate medical outcomes. Managing patient relationships across borders requires more in-depth understanding of patient needs in order to help foreign patients understand their contractual obligations, as well providing a more effective services marketing ethic. Consequently, "medical tourists" requires better research to explore attributes and impacts on health marketing services provision.

\section{References}

Al-Damen, R. (2017). Health Care Service Quality and Its Impact on Patient Satisfaction "Case of Al-Bashir Hospital”. International Journal of Business and Management, 12(9), 136-152. https://doi.org/10.5539/ijbm.v12n9p136

Altheide, D., \& Johnson, J. (1998). Criteria for assessing interpretive validity in qualitative research. In: Denzin, N., \& Lincoln, Y. (Eds.), Collecting and interpreting qualitative materials (pp. 283-312). Thousand Oaks, CA: Sage Publications. 
de Arellano, R. (2007). Patients without Borders: The Emergence of Medical Tourism. International Journal of Health Services, 37(1), 193-198. https://doi.org/10.2190/4857-468G-2325-47UU

Arksey, H., \& O'Malley, L. (2005). Scoping studies: Towards a Methodological Framework. International Journal of Social Research Methodology, 8(1), 19-32. https://doi.org/10.1080/1364557032000119616

Bahadori, M., Malmir, R., Alimohammadzadeh, K. Yagoubi, M., \& Hosseini, S. (2017). Identifying and Prioritizing Barriers to Health Tourism Using the Analytical Hierarchy Process. International Journal of Travel Medicine and Global Health, 5(1), 33-35. https://doi.org/10.15171/ijtmgh.2017.06

Bailey, K. (2008). Methods of Social Research. New York, NY: The Free Press.

Balshem, M. (1991). Cancer, Control and Causality: Talking about Cancer in a Working-Class Community. American Ethnologist, $18(1), \quad$ 152-172. https://doi.org/10.1525/ae.1991.18.1.02a00070

Bangkok Post. (2017). Visa extension scheme to push medical hub target. Retrieved from https://www.bangkokpost.com/business/1305759/visa-extension-scheme-to-push-medical-hu b-target

Bangkok Post. (2018). K-Research: Foreigners key for hospitals. Retrieved from https://www.bangkokpost.com/business/news/1483849/k-research-foreigners-key-for-hospita ls

Bello, D., \& Holbrook, M. (1995). Does and Absence of Brand Equity Generalize Across Product Classes. Journal of Business Research, 34(2), 125-131. https://doi.org/10.1016/0148-2963(95)00008-G

Benn, N., Buckingham, S., Domingue, J., \& Mancini, C. (2008). Ontological Foundations for Scholarly Debate Mapping Technology. In: 2nd International Conference on Computational Models of Argument (COMMA '08), Toulouse, France.

Bhangale, V. (2011). Marketing of healthcare services in India: a study on factors influencing patients' decision making on choice of a hospital. Journal of Management and Marketing in Healthcare, 4(4), 229-233. https://doi.org/10.1179/175330311X12943314049376

Bochaton, A., \& Lefebvre, B. (2008). The rebirth of the hospital: Heterotopia and medical tourism in Asia. Asia on Tour: Exploring the rise of Asian tourism, 2008. HAL Id: hal-01802299

Borman, E. (2004). Health tourism: Where healthcare, ethics, and the state collide. $B M J$, 328(7431), 60-61. https://doi.org/10.1136/bmj.328.7431.60

Carman, J. (2000). Patient Perceptions of Service Quality: Combining the Dimensions. Journal of Services Marketing, 14(4), 337-352. https://doi.org/10.1108/08876040010334565 
Carman, J. (1990). Consumer Perceptions of Service Quality: An Assessment of the SERVQUAL Dimensions. Journal of Retailing, 66(1), 33-55.

Carrera, P., \& Bridges, J. (2006). Globalization and Healthcare: Understanding Health and Medical Tourism. Expert Review of Pharmacoeconomics and Outcomes Research, 6(4), 447-454. https://doi.org/10.1586/14737167.6.4.447

Cassell, C., \& Symon, G. (2004). Essential Guide to Qualitative Methods in Organizational Research. (Eds). Sage Publications, London, UK.

Charmaz, K. (2006). Constructing Grounded Theory: A Practical Guide through Qualitative Analysis. Sage Publications, London, UK.

Chauvot, P. (2011). The Importance of Language Skills in Hospitals. Communicaid, $29^{\text {th }}$ July 2011.

https://www.communicaid.com/business-language-courses/blog/the-importance-of-languageskills-in-hospitals/

Cheek, R., \& Chandra, A. (2002). International Health Care for Expatriates and Travellers through Telemedicine: A Discussion. Journal of Health Management, 4(1), 31-37. https://doi.org/10.1177/097206340200400104

Choi, K., Cho, W., Lee, S., Lee, H., \& Kim, C. (2004). The relationships among quality, value, satisfaction and behavioral intention in health care provider choice: A South Korean study. Journal of Business Research, 57(8), 913-921. https://doi.org/10.1016/S0148-2963(02)00293-X

Clark, W., \& Clark, L. (2007). Measuring functional service quality using SERVQUAL in a high-dependence health service relationship. Health Care Management, 26(4), 306-317. https://doi.org/10.1097/01.HCM.0000299248.53441.e9

Connell, J. (2006). Medical tourism: sea, sun, sand and ...surgery. Tourism Management, 27(6), 1093-1100. https://doi.org/10.1016/j.tourman.2005.11.005

Comandé, G. (2009). Patients' Medical Tourism and Electronic Health Records: Mobility between Sector Regulations and Systemic Interactions. In: Aurelia Colombi Ciacchi, Christine Godt, Peter Rott, Lesley Jane Smith (Hrsg.), Haftungsrecht im dritten Millennium - Liability in the Third Millennium, Seite, 331-344.

Coombes, C. (2017). Coherence and transparency: some advice for qualitative researchers. Production, 27. https://doi.org/10.1590/0103-6513.006817

Crane, F., Kerin, R., Hartley, S., \& Rudelius, W. (2011). Marketing. Toronto, Ontario: McGraw-Hill Ryerson.

Cronin, J., Brady, M., \& Hult, T. (2000). Assessing the effects of quality, value, and customer satisfaction on consumer behavioral intensions in service environments. Journal of Retailing, 79(2), 193-218. https://doi.org/10.1016/S0022-4359(00)00028-2 


\section{$\triangle$ Macrothink}

Journal of Management Research ISSN 1941-899X

Cutler, D., \& Morton, F. (2013). Hospitals, Market Share, and Consolidation. Clinical Review \& Education, 310(18), 1964-1970.

Daniels, J., Bradley, M., Cramer, D., Winkler, A., Kinebrew, K., \& Crockett, D. (2007). The Successful Resolution of Armed Hostage/Barricade Events in Schools: A Qualitative Analysis. Psychology in the Schools, 44(6), 601-613. https://doi.org/10.1002/pits.20250

Devers, K., Brewster, L., \& Casalino, L. (2003). Changes in Hospital Competitive Strategy: A New Medical Arms Race? Health Services Research, 38(1 Pt 2), 447-469. https://doi.org/10.1111/1475-6773.00124

Dey, I. (2005). Qualitative data analysis. London, UK: Routledge.

Dimitrov, D. (2016). Medical Internet of Things and Big Data in Healthcare. Healthcare Informatics Research, 22(3), 156-163. https://doi.org/10.4258/hir.2016.22.3.156

Dooley, J., Jones, S., \& Iverson, D. (2014). Using Web 2.0 for health promotion and social marketing efforts: lessons learned from Web 2.0 experts. Health Marketing Quarterly, 31(2), 178-196. https://doi.org/10.1080/07359683.2014.907204

Duranti, A. (2007). Transcripts, like Shadows on a Wall. Mind, Culture, and Activity, 13(4), 301-310. https://doi.org/10.1207/s15327884mca1304_3

Fink, A. (2000). The Role of the Researcher in the Qualitative Research Process. A Potential Barrier to Archiving Qualitative Data. Forum: Qualitative Social Research, 1(3), article 4.

Fischer, S., Pelka, S., \& Riedl, R. (2015). Understanding patients' decision-making strategies in hospital choice: Literature review and a call for experimental research. Cogent Psychology, 2(1). https://doi.org/10.1080/23311908.2015.1116758

Footman, K., Knai, C., Baeten, R., Glonti, K., \& McKee, M. (2014). Cross-border health care in Europe, Policy Summary 14, WHO, Denmark. Retrieved from http://www.euro.who.int/_data/assets/pdf_file/0009/263538/Cross-border-health-care-in-Eur ope-Eng.pdf

Fraenkel, L. (2013). Incorporating Patients' Preferences into Medical Decision Making. Medical Care Research Review, 70(10): 80S-93S. https://doi.org/10.1177/1077558712461283

Fraser, I., Encinosa, W., \& Glied, S. (2008). Improving Efficiency and Value in Health Care: Introduction. Health Services Research, 43(5 Pt 2), 1781-1786. https://doi.org/10.1111/j.1475-6773.2008.00904.x

Fry, M., Curtis, K., Considine, J., \& Shaban, R. (2017). Using observation to collect data in emergency research. Australasian Emergency Nursing Journal, 2(1), 25-30. https://doi.org/10.1016/j.aenj.2017.01.001

García-Altés, A. (2005). The Development of Health Tourism Services. Annals of Tourism Research, 32(1), 262-266. 
Gill, L., \& White, L. (2009). A critical review of patient satisfaction. Leadership in Health Services, 22(1), 8-19. https://doi.org/10.1108/17511870910927994

Glaser, B. (1992). Basics of Grounded Theory Analysis. Mill Valley, CA: Sociology Press.

Glaser, B., \& Strauss, A. (1967). The Discovery of Grounded Theory: Strategies for Qualitative Research. Chicago: Aldine.

Glinos, I. (2011). Cross-border collaboration. In: Wismar M, Palm W, Figueras J, Ernst K and Van Ginneken E, eds. Cross-border health care in the European Union: mapping and analysing practices and policies. Copenhagen, WHO Regional Office for Europe on behalf of the European Observatory on Health Systems and Policies (Observatory Studies Series, 22, 217-254).

Goi, C. (2009). A Review of Marketing Mix: 4Ps or More? International Journal of Marketing Studies, 1(1), 1-14. https://doi.org/10.5539/ijms.v1n1p2

Gonzalez, C. (2008). Conceptions of, and approaches to, teaching online: a study of lecturers teaching postgraduate distance courses. Higher Education, 57(3), 299-314. https://doi.org/10.1007/s10734-008-9145-1

Gordon, S., Feldman, D., \& Leonard, M. (2014). Collaborative Caring. London, UK: ILR Press, Cornell University.

Gray, J., \& Wilcox, B. (1995). Good Schools, Bad Schools. Buckingham, UK: Open University Press.

Grönroos, C. (1999). Internationalization strategies for services. Journal of Services Marketing, 13(4-5), 290-297. https://doi.org/10.1108/08876049910282547

Han, H., \& Hyun, S. (2015). Customer retention in the medical tourism industry: Impact of quality, satisfaction, trust, and price reasonableness. Tourism Management, 46, 20-29. https://doi.org/10.1016/j.tourman.2014.06.003

Hanefeld, J., Horsfall, D., Lunt, N., \& Smith, R. (2013). Medical Tourism: A Cost or Benefit to the NHS? PLOS. https://doi.org/10.1371/journal.pone.0070406

Hareide, P., Bjorberg, S., Store-Valen, M., Haddadi, A., \& Lohne, J. (2016). Strategies for Optimization of Value in Hospital Buildings. Procedia - Social and Behavioral Sciences, 226, 423-430. https://doi.org/10.1016/j.sbspro.2016.06.207

Harris, L., \& Brown, G. (2010). Mixing interview and questionnaire methods: Practical problems in aligning data. Practical Assessment, Research and Evaluation, 15(1), 1-19.

Harwood, T., \& Garry, T. (2003). An Overview of Content Analysis. The Marketing Review, 3(4), 479-498. https://doi.org/10.1362/146934703771910080

Holmqvist, J. (2011) Consumer language preferences in service encounters: a cross-cultural perspective. Managing Service Quality, 21(2), 178-191. https://doi.org/10.1108/09604521111113456 


\section{NI Macrothink}

Journal of Management Research ISSN 1941-899X 2020, Vol. 12, No. 1

Horowitz, M., \& Rosensweig, J. (2007). Medical tourism: Health Care in the global economy. The Physician Executive, 33(6), 24-30. PMID: 18092615

Horowitz, M., Rosensweig, J., \& Jones, C. (2007). Medical Tourism: Globalization of the Healthcare Marketplace. Medscape General Medicine, 9(4), 33. PMID: 18311383

Irvine, A., Drew, P., \& Sainsbury, R. (2012). “Am I not answering your questions properly?" Clarification, adequacy and responsiveness in semi-structured telephone and face-to-face interviews. Qualitative Research, 13(1), 87-106. https://doi.org/10.1177/1468794112439086

Jacobs, E., Shepard, D., Suaya, J., \& Stone, E. (2004). Overcoming Language Barriers in Health Care: Costs and Benefits of Interpreter Services. American Journal of Public Health, 94(5), 866-869. PMID: 15117713

James, P. (2015). Social Media Marketing Developments in Private Hospitals in Bangkok. The Internet Journal of Healthcare Administration, 11(1). https://doi.org/10.5580/IJHCA.35596

James, P. (2014). Managerial Challenges Impacting on Contractor Led Tunnel TBM Design: A Kingdom of Saudi Arabia Metro Project. Engineering Management Research, 3(2), November, 2014. https://doi.org/10.5539/emr.v3n2p32

James, P. (2012). The impact of medical tourism on Thai private hospital management: informing hospital policy. Global Journal of Health Science, 4(1), 127-139. https://doi.org/10.5539/gjhs.v4n1p127

James, P. (2005). Total Quality Management in Asia: Practices for the 21st Century. Singapore: Pearson.

James, P., \& James, T. (2011). Qualitative Research Methods for Health Services. London, UK: Megellan UK Press.

Jiang, P., \& Rosenbloom, B. (2005). Customer intention to return online: price perception, attribute-level performance, and satisfaction unfolding over time. European Journal of Marketing, 39(1/2), 150-174. https://doi.org/10.1108/03090560510572061

Johnson, B. (1997). Examining the validity structure of qualitative research. Education, 118(3), 282-292.

Johnson, R., Crooks, V., Snyder, J., \& Kingsbury, P. (2010). What is known about the effects of medical tourism in destination and departure countries? A scoping review. International Journal of Equity in Health, 9(1), 24. https://doi.org/10.1186/1475-9276-9-24

Joynt, K., Orav, J., \& Jha, A. (2014). Association Between Hospital Conversions to For-Profit Status and Clinical and Economic Outcomes. JAMA, 312(16), 1644-1652. https://doi.org/10.1001/jama.2014.13336

Kaiser, K. (2009). Protecting Respondent Confidentiality in Qualitative Research. Qualitative Health Research, 19(11), 1632-1641. https://doi.org/10.1177/1049732309350879 
Kangas, B. (2010). Traveling for Medical Care in a Global World. Medical Anthropology: Cross-Cultural Studies in Health and Illness, 29(4), 344-362. https://doi.org/10.1080/01459740.2010.501315

Kanibir, H., \& Nart, S. (2012). The Effects of Internal Relationship Marketing on Superior Customer Relations as Competitive Performance: Evidence from Healthcare Industry. Procedia - Social and Behavioral Sciences, 58, 1378-1385. https://doi.org/10.1016/j.sbspro.2012.09.1122

Karuppan, C. (2009). Healthcare Tourism: Accelerating diffusion through a more effective use of communication channels. Journal of Communication in Health, 3(1), 24-36. https://doi.org/10.1179/cih.2010.3.1.24

Keckley, P., \& Underwood, H. (2008). Medical Tourism: Consumers in Search of Value. Deloitte Center for Health Solutions. Retrieved from www.deloitte.com/dtt/cda/doc/content/us_chs_MedicalTourismStudy(1).pdf

Kelley, E. (2013). Medical Tourism. WHO, Patient Safety, $2^{\text {nd }}$ October. Retrieved from http://www.who.int/global_health_histories/seminars/kelley_presentation_medical_tourism.p df

Kim, Y. (2011). The Pilot Study in Qualitative Inquiry: Identifying Issues and Learning Lessons for Culturally Competent Research. Qualitative Social Work, 10(2), 190-206. https://doi.org/10.1177/1473325010362001

Kvale, S. (1996). Interviews: An Introduction to Qualitative Research Interviewing. Thousand Oaks, CA: Sage Publications.

Lagiewsky, R., \& Myers, W. (2008). Medical tourism: Perspective and applications for destination development. Dubrovnik, Croatia: American collage of Management and Technology. Retrieved from http://scholarworks.rit.edu/other/683

Lambsdorff, G. (1998). An Empirical Investigation of Bribery in International Trade. European Journal for Development Research, 10(1), 40-59. https://doi.org/10.1080/09578819808426701

Li, S., Huang, Y., \& Yang, M. (2011). How satisfaction modifies the strength of the influence of perceived service quality on behavioral intentions. Leadership in Health Services, 24(2), 91-105. https://doi.org/10.1108/17511871111125675

Lin, Y., \& Lin, Y. (2010). Health-promoting organization and organizational effectiveness of health promotion in hospitals: a national cross-sectional survey in Taiwan. Health Promotion International, 26(3), 362-375. https://doi.org/10.1093/heapro/daq068

Lincoln, Y., \& Guba, E. (1985). Naturalistic Inquiry. Beverly Hills, CA: Sage Publications.

Lunt, N., Hardey, M., \& Mannion, R. (2010). Nip, tuck and click: medical tourism and the emergence of web-based health information. Open Medical Information Journal, 12(4), 1-11. https://doi.org/10.2174/1874431101004010001 
Lynch, J., \& Schalet, D. (1999). Consumer Evaluation of the Quality of Hospital Services From an Economics of Information Perspective. Journal of Health Care Marketing, 10(2), 16-22. PMID: 10105192

Marcella, R., \& Davies, S. (2004). The use of customer language in international marketing communication in the Scottish food and drink industry. European Journal of Marketing, 38(11/12), 1382-1395. https://doi.org/10.1108/03090560410560155

Mascia, D., Vincenzo, F., \& Cicchetti, A. (2012). Dynamic analysis of interhospital collaboration and competition: Empirical evidence from an Italian regional health system. Health Policy, 105(2-3), 273-281. https://doi.org/10.1016/j.healthpol.2012.02.011

Masoud, F., Alireza, J., Mahmoud, K., \& Zahra, A. (2013). A systematic review of publications studies on medical tourism. Journal of Educational Health Promotion, 2, 51. https://doi.org/10.4103/2277-9531.119037

Maxwell, J. (2013). Qualitative Research Design: An Interactive Approach. London, UK: Sage Publications.

McFadden, L., Stock, N., \& Gowen, R. (2006). Implementation of patient safety initiatives in US hospitals. International Journal of Operations \& Production Management, 26(3), 326-347. https://doi.org/10.1108/01443570610651052

Meurer, W., Frederiksen, S., Majersik, J., Zhang, L., Sandretto, A., \& Scott, P. (2007). Qualitative Data Collection and Analysis Methods: The INSTINCT Trial. Academic Emergency Medicine, 14, 1064-1071. https://doi.org/10.1197/j.aem.2007.05.005

Murti, A., Deshpande, A., \& Srivastava, N. (2013). Service Quality, Customer (Patient) Satisfaction and Behavioural Intention in Health Care Services: Exploring the Indian Perspective. Journal of Health Management, 15(1), 29-44. https://doi.org/10.1177/0972063413486035

Nagarajan, G. (2004). Medical tourism in India: strategy for the development. Banglore, India: Crisil young leader series.

Newsome, P., \& Wright, G. (1999). A review of patient satisfaction: 1. Concepts of satisfaction. British Dental Journal, 186(4), 161-165.

Noree, T., Hanefeld, J., \& Smith, R.. (2016). Medical tourism in Thailand: a cross-sectional study. Bulletin of the World Health Organization,94(1), 30 - 36. World Health Organization. http://dx.doi.org/10.2471/BLT.14.152165

Onwuegbuzie, A., \& Leech, N. (2007). Sampling Designs in Qualitative Research: Making the Sampling Process More Public. The Qualitative Report, 12(2), 238-254.

Owusu-Frimpong, N., Nwankwo, S., \& Dason, B. (2010). Measuring service quality and patient satisfaction with access to public and private healthcare delivery. International Journal of Public Sector Management, 23(3), 203-200. https://doi.org/10.1108/09513551011032455 
Phillippi, J., \& Lauderdale, J. (2017). A Guide to Field Notes for Qualitative Research: Context and Conversation. Qualitative Health Journal, 28(3), 381-388. https://doi.org/10.1177/1049732317697102

Punch, K. (2014). Introduction to Social Research: Quantitative and Qualitative Approaches. London, UK: Sage Publications.

Pyke, S., Hartwell, H., Blake, A., \& Hemingway, A. (2016). Exploring well-being as a tourism product resource. Tourism Management, 55, 94-105. https://doi.org/10.1016/j.tourman.2016.02.004

Qu, S., \& Dumay, J. (2011). The qualitative research interview. Qualitative Research in Accounting \& Management, 8(3), 238-264. https://doi.org/10.1108/11766091111162070

Raju, P., \& Lonial, S. (2002). The impact of service quality and marketing on financial performance in the hospital: An empirical examination. Journal of Retailing and Consumer Service, 9(6), 335-348. https://doi.org/10.1016/S0969-6989(02)00003-6

Ranney, M., Meisel, Z., Choo, E., Garro, A., Sasson, C., \& Guthrie, K. (2015). Interview-based qualitative research in emergency care part II: data collection, analysis and results reporting. Academic Emergency Medicine, 22(9), 1103-1112. https://doi.org/10.1111/acem.12735

Rashdi, I. (2011). How Much the Quality of Healthcare Costs? A Challenging Question! Oman Medical Journal, 26(5), 301-302. https://doi.org/10.5001/omj.2001.76

Ratner, C. (2012). Understanding the TEMOS approach to quality and accreditation in medical tourism. International Medical Travel Journal. Retrieved from www.imtj.com.

Ritchie, J., \& Lewis, J. (2003). Qualitative Research Practice: A Guide for Social Science Students and Researchers. London, UK: Sage Publications.

Rivers, P., \& Glover, S. (2008). Health care competition, strategic mission, and patient satisfaction: research model and propositions. Journal of Organ Management, 22(6), 627-641. https://doi.org/10.1108/14777260810916597

Rokni, L., Avci, T., \& Park, S. (2017). Barriers of Developing Medical Tourism in a Destination: A Case of South Korea. Iranian Journal of Public Health, 46(7), July. PMID: 28845404

Rubin, H., \& Rubin, I. (2005). Qualitative Interviewing: The Art of Hearing Data. Thousand Oaks, CA: Sage Publications.

Sbaraini, A., Carter, S., Wendell Evans, R., \& Blinkhorn, A. (2011). How to Do a Grounded Theory Study: A Worked Example of a Study of Dental Practices. BMC Medical Research Methodology, 11, 128. https://doi.org/10.1186/1471-2288-11-128

Seale, C., \& Silverman, D. (1997). Ensuring rigour in qualitative research. European Journal of Public Health, 7(4), 379-384. https://doi.org/10.1093/eurpub/7.4.379 


\section{Macrothink}

Journal of Management Research

ISSN 1941-899X

2020, Vol. 12, No. 1

Sheaff, R. (2002). Responsive Healthcare: Marketing for a public service. Buckingham, UK: Open University Books.

Sinha, A. (2017). The Role of Team Effectiveness in Quality of Health Care. Integrative Journal of Global Health, 1(1), 1-4.

Smith, R., Lunt, N., \& Hanefeld, J. (2012). The implications of PIP are more than just cosmetic. Lancet. $\quad M a r \quad 31, \quad 379(9822), 1180-1181$. https://doi.org/10.1016/S0140-6736(12)60166-4 PMID: 22305764

Sobo, E. (2009). Medical Travel: What it Means, Why it Matters. Medical Anthropology, 28(4), 326-335. https://doi.org/10.1080/01459740903303894

Spanos, A. (1990). Towards a Unifying Methodological Framework. In: Modelling Economic Series: Readings in Econometric Methodology. In: William, C. \& Granger, J. Readings in Econometric Methodology, Oxford, UK: Clarendon Press.

Speziale, G. (2015). Strategic management of a healthcare organization: engagement, behavioural indicators, and clinical performance. European Heart Journal Supplements, 17(suppl_A), A3-A7.https://doi.org/10.1093/eurheartj/suv003

Stenbacka, C. (2001). Qualitative research requires quality concepts of its own. Management Decision, 39(7), 551-556. https://doi.org/10.1108/EUM0000000005801

Strauss, A., \& Corbin, J. (1990). Basics of Qualitative Research: Grounded Theory, Procedures and Techniques. Newbury Park, Chicago: Sage Publications.

Sutton, J., \& Austin, Z. (2015). Qualitative Research: Data Collection, Analysis, and Management. Canadian Journal of Hospital Pharmacy, 68(3), 226-231. PMID: 26157184

Thomas, R. (2005). Marketing Health Service. Chicago: Health Administration Press.

TravelInsurance.com. (2017). Why Medical Tourism Is Not Covered By Travel Insurance. Retrieved from https://www.travelinsurance.com/2017/04/medical-tourism-not-covered-travel-insurance/

Turner, L. (2010). "Medical Tourism" and the global marketplace in health services: US patients, international hospitals, and the search for affordable health care. International Journal of Health Services, 40(3), 443-467. https://doi.org/10.2190/HS.40.3.d

Turner, L. (2007). First World Health Care at Third World Prices: Globalisation, Bioethics and Medical Tourism. BioSocieties, 2(3), 303-325. https://doi.org/10.1017/S1745855207005765

Uzun, V., \& Bilgin, S. (2016). Evaluation and implementation of QR Code Identity Tag system for Healthcare in Turkey. Springerplus, 5(1), 1454. https://doi.org/10.1186/s40064-016-3020-9 PMID: 27652030

Vargo, S., \& Lusch, R. (2004). Evolving to a new dominant logic for marketing. Journal of Marketing, 68(1), 1-17. https://doi.org/10.1509/jmkg.68.1.1.24036 


\section{Macrothink}

Journal of Management Research

ISSN 1941-899X 2020, Vol. 12, No. 1

Voorhees, C., Fombelle, P., Gregoire, Y., Bone, S., Gustafsson, A., Sousa, R., \& Walowiak, T. (2017). Service encounters, experiences and the customer journey: Defining the field and a call to expand our lens. Journal of Business Research, 79, 269-280. https://doi.org/10.1016/j.jbusres.2017.04.014

Walsh, S., White, K., \& Young, R. (2008). Over-Connected? A Qualitative Exploration of the Relationship between Australian Youth and Their Mobile Phones. Journal of Adolescence, 31(1), 77-92. https://doi.org/10.1016/j.adolescence.2007.04.004

Ward, P., Rokkas, P., Cenko, C., Pulvirenti, M., Dean, N., Carney, S., Brown, P., Calnan, M., \& Meyer, S. (2015). A qualitative study of patient (dis)trust in public and private hospitals: the importance of choice and pragmatic acceptance for trust considerations in South Australia. BMC Health Services Research, 15(1), 297-308. https://doi.org/10.1186/s12913-015-0967-0

Westhues, A., Ochocka J., Jacobson N., Simich, L., Maiter, S., Janzen, R., \& Fleras, A. (2008). Developing a Theory from Complexity: Reflections on a Collaborative Mixed Method Participatory Action Research Study. Qualitative Health Research, 18(5), 701-717. https://doi.org/10.1177/1049732308316531

Yoon, H., Cho, S., \& Suguaran, V. (2011). A Service System Design to Support Medical Tourism in South Korea. International Conference on Information Resources Management (CONF-IRM), CONF-IRM 2011 Proceedings. Retrieved from http://aisel.aisnet.org/confirm2011/11

Young, S., \& Erdem, S. (1996). An Exploratory Study of Services Marketing in Global Markets: Major Areas of Inquiry for the Health Care Services Industry. Health Marketing Quarterly, 14(1), 85-98. https://doi.org/10.1300/J026v14n01_07

Zeithaml, V., Berry, L., \& Parasuraman, A. (1996). The behavioural consequences of service quality. Journal of Marketing, 60(2), 31-46. https://doi.org/10.2307/1251929 